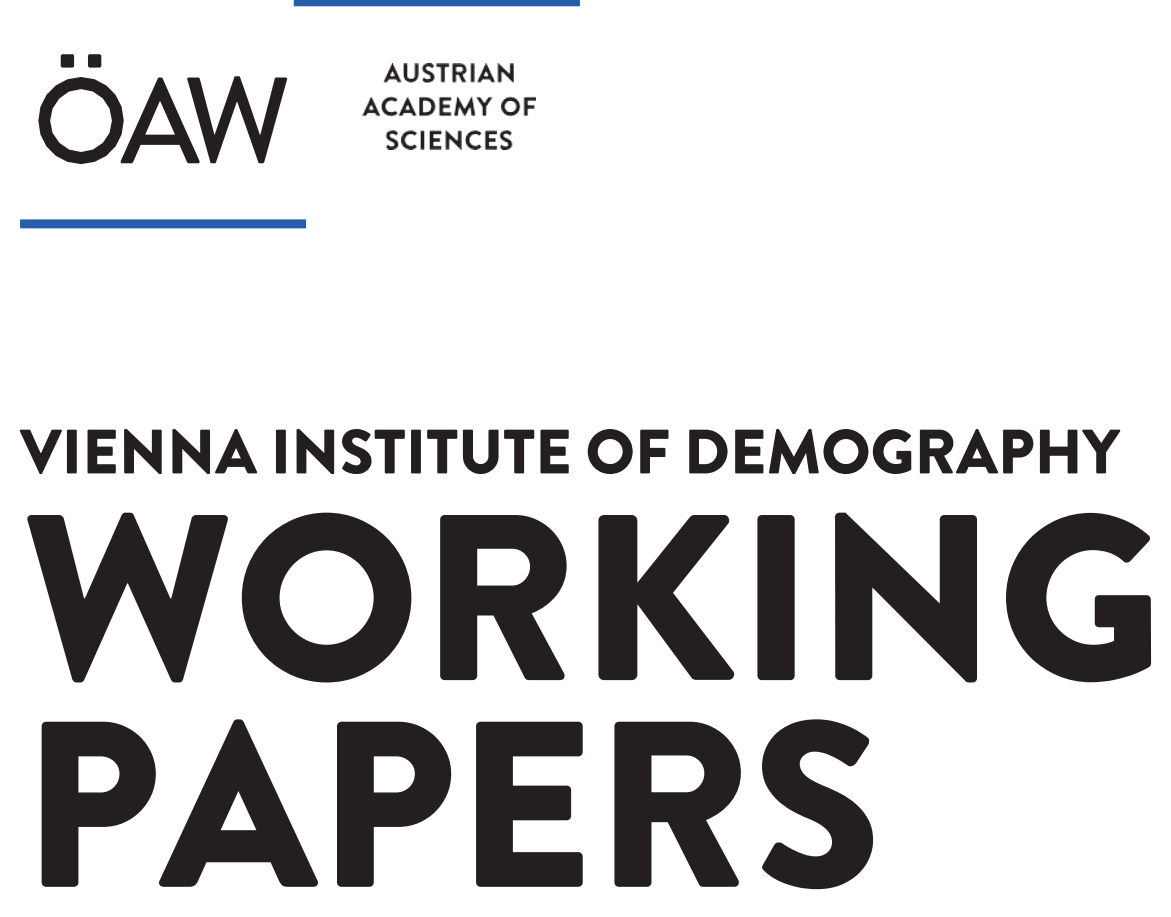

$03 / 2021$

\title{
MEASURING THE EFFECT OF EMPLOYMENT UNCERTAINTY ON FERTILITY IN EUROPE
} (A LITERATURE REVIEW)

\section{BRIAN BUH}




\section{ABSTRACT}

Numerous studies have looked at the effect that employment uncertainty has on fertility/childbearing. However, there is a lack of consensus about how to conceptualise and measure it. This paper first reviews issues surrounding the conceptualisation and existing measures of employment uncertainty. It then reviews existing measure of employment uncertainty in the context of fertility decisions. Finally, it raises considerations about their use while suggesting directions for further study.

\section{KEYWORDS}

Employment uncertainty, fertility, job instability, measuring uncertainty

\section{AUTHOR}

Brian Buh, Wittgenstein Centre for Demography and Global Human Capital (IIASA, OeAW, University of Vienna), Vienna Institute of Demography/Austrian Academy of Sciences. Email: brian.buh@oeaw.ac.at

\section{ACKNOWLEDGEMENTS}

I would like to thank Isabella Buber-Ennser for her guidance through several drafts, Ross Barker for his insight and Leora Courtney-Wolfman for proofreading the manuscript.

This study was conducted within the Birthlife project funded by the Austrian Research Foundation (FWF, P 31357-G29). 


\section{INTRODUCTION}

Growing employment uncertainty in advanced economies and its relationship to fertility has received significant attention in recent decades (e.g. Adsera, 2011; Dupray \& Pailhé, 2018; Kreyenfeld et al., 2012). However, diverging results and complex interdependencies compel the need to review approaches and measurements in a systematic way. It is clear from previous fertility research that uncertainty includes micro-level objective measures of employment, subjective perceptions, structural components, life-long trends, and emerging trends within countries.

Evidence from the last recession shows that fertility rates dropped more in regions with higher unemployment rates and where labour market conditions deteriorated at a higher rate than regions less affected by the recession (Matysiak et al., 2020). However, even countries that emerged from the recession largely unscathed have seen a decline in total fertility rates (TFR). For example, Norway saw fertility rates drop from 1.98 in 2009 to 1.6 in 2018 (Hellstrand et al., 2020). Additionally, TFRs have not recovered in Southern and Eastern European countries with lowest-low fertility rates (TFR 1.3 or lower) despite their economic recoveries (Comolli, 2017). This suggests that the macro-economic explanations linking TFR to unemployment rates do not capture the dynamic effects of employment in individuals' lives.

Instead, the continued decrease in fertility may be tied to micro-level changes. Early theories addressing the role of employment on fertility and childbearing focus on the effects of unemployment. The microeconomic model of fertility theorises that unemployment produces two competing effects on the demand for children (Becker, 1960). One the one hand, the income effect constrains the demand for children by reducing available financial resources needed for childrearing. On the other hand, the substitution effect lowers the opportunity cost of childbearing, thus increasing the demand for children. Both effects have been observed empirically, although the substitution effect has been primarily observed for women (Adsera, 2004). Evidence from a meta-analysis of studies looking at the effect of unemployment on fertility rates indicates that the effect unemployment has on reducing fertility outcomes in Europe has become stronger over the last few decades (Alderotti et al. , 2021). However, the effect of unemployment on fertility is mitigated by different welfare systems (Gauthier, 2007). Countries with strong welfare systems may provide a sense of security that counteracts the negative effects of unemployment and allows parents to make longer term plans. This implies that uncertainty arising from employment affects fertility more than short-term employment status. Unemployment alone is just one of the many aspects of employment uncertainty.

Since employment uncertainty is much more complex than unemployment, several approaches have emerged to measure employment uncertainty within the realm of fertility research. Theory in the fields of uncertainty and fertility suggest that interlinkages of life course domains, past experiences, and future perceptions make simple indicators insufficient (Bernardi et al., 2019; Vignoli et al., 2020a). Recent attempts have been made to create indicators that study the effects of uncertainty based on individual employment histories and perceptions of future uncertainty (Busetta et al., 2019; Fahlén \& Oláh, 2018). There is also a rich body of literature linking fertility and the life course (Billari, 2001; Huinink \& Kohli, 2014; Liefbroer \& ZoutewelleTerovan, 2021).Considering the complications around conceptualising and measuring employment uncertainty, this paper aims to provide a systematic review of previous employment uncertainty measures in the field of fertility in Europe. It assesses these issues by conceptualising employment uncertainty, reviews the indicators introduced in the literature, considers the pros and cons of current indicators, and provides considerations for future research in the field.

The paper is structured as follows: Section 2 looks at the conceptualisation of employment uncertainty and what effect this has on methodology. Section 3 describes the main indicators introduced in the literature. Section 4 discusses considerations when making measurement choices, and Section 5 concludes.

\section{CONCEPTS}

The definition of uncertainty remains debated within fertility research. Vignoli et al. (2020a) classify definitions of general life course uncertainty into three categories: social interaction, available information, and fundamental uncertainty. Uncertainty by social interaction is defined as the inability to predict the behaviour of others since all individuals are simultaneously learning and adapting (Elster, 2009). Uncertainty results from a lack of available information when individuals have neither the ability nor the 
time to collect information or are unaware of its existence (Davidson, 1996). In both cases, the uncertainty arises from the inability to properly forecast future risks or probabilities.

Fundamental uncertainty is defined as uncertainty which arises from future outcomes that inherently cannot be forecasted or even potentially known (Beckert, 2016). With regards to employment, this type of uncertainty, studied through the lens of globalisation, started gain prominence in the 1980s (Hacker, 2019). Substantial transformations in labour market dynamics over the last forty years have profoundly changed structural and individual employment security (Gebel \& Giesecke, 2011; Mills \& Blossfeld, 2003; Peters, 2008). For example, market internationalisation make them increasingly relevant to all aspects of life, making employment more sensitive to the dynamic nature of price and competition (Beck, 1992; Gottfried, 2014). However, fundamental uncertainty may affect individuals' behaviour differently depending on their capacity and willingness to accept the unknown. Most individuals will experience uncertainty at some point, but when, how, and the scale in which they experience it varies greatly (Mayer, 2009). Intensified competition additionally contributes to uncertainty by increasing the need to acquire more human capital, postponing the entry into parenthood (Blossfeld et al., 2006; Kohler et al., 2002). When linking employment uncertainty and fertility, it is this postponement effect as well as the proximity of uncertainty surrounding childbearing decisions that affect fertility intention (Bernardi et al., 2015). It is with this understanding of the multiple manifestations of uncertainty that researchers need to clearly define what they specifically want to study.

Using the above classifications of uncertainty, employment uncertainty can be defined as: Individuals experience employment uncertainty when stability in employment is not, or is not perceived as, guaranteed (Anderson \& Pontusson, 2007; Esser \& Olsen, 2012). Employment uncertainty can be institutionalised (fixed-term contracts, seasonal or temporary employment, selfemployment, or involuntary part-time employment) or perceived (Hofmeister et al., 2006; Trevor-Roberts, 2006). Additionally, there is significant occupational psychology literature on job instability, which is a similar concept with a similar definition (Cheng \& Chan, 2008; Sverke et al., 2002).

However, the above definition does not provide a clear guideline on how to measure employment uncertainty. Most measurements fall into two larger categories: objective measures, which look at previous or current employment situations and subjective measures, which ask individuals to evaluate present and future risks. These measures can be further subcategorised as macro and micro measures as well as absolute and relative measures.

Objective measures of employment uncertainty focus on individuals' risk factors like employment status or contract type. Job stability, assessed through contract length and type as well as time spent out of paid employment, is the most studied aspect of employment uncertainty, as it is easiest to quantify (Adsera, 2011a; Barbieri et al., 2015; Golsch, 2003). Objective measures are typically framed as looking for evidence of economic insecurity. A common approach examines the relationship between other sociodemographic characteristics, like educational attainment, ethnicity, or household wealth, and the ability to secure stable employment as a form of economic security. Objective measures are either absolute (e.g., employment status, contract type, income) or relative (e.g., loss of income from job loss, employment situation versus partner's, income category versus median income) (Kreyenfeld, 2016; Testa \& Toulemon, 2006). Relative measures are bound within a certain range (e.g., 0 to 1), while absolute measures are either continuous or categorical. However, objective measures do not capture interpersonal differences in the experience or perception of employment uncertainty-something better fit for subjective measures.

Subjective measures are generally elicited by means of individual surveys, which include questions about levels of perceived employment security or associated stressors (e.g., likelihood to lose a job, perception of worsening financial situation). This includes financial and employment security, job-related characteristics, and/or issues related to work-family reconciliation (e.g. Begall \& Mills, 2011; Fahlén, 2013; Fahlén \& Oláh, 2018).

The perception of uncertainty arises from individual (micro) experiences, but is also influenced by community or society-wide changes. Therefore, macro measures are practical for studying individual uncertainty and are often an aggregate of individualspecific measurements, but some influential measures are computed directly at the macro-level (e.g., consumer confidence index). This includes measures like national and local unemployment rates as well as the share of specific contractual agreements (e.g., share of public sector employees, part-time work, or fixed-term contracts) (Adsera, 2004). Recent work has started to look at how macro-subjective perceptions of employment uncertainty (at the community and national level) influence individual fertility behaviour (Vignoli et al., 2020a).

Finally, employment uncertainty differs from concepts like income volatility and economic insecurity. Income volatility is generally a backward-looking objective measure, but highly related to employment uncertainty (Iceland, 2005). While income 
volatility might overlap with periods of employment uncertainty, the two concepts differ (e.g., a self-employed person may have a highly volatile income, but may not feel insecure about their employment). Moreover, economic insecurity, oftentimes conflated with employment uncertainty, is a much broader topic that incorporates the individual's financial and human capital and their ability to handle economically difficult times and escape financially tenuous situations (Richiardi \& He, 2019). For example, highly educated persons may experience long periods of employment uncertainty, particularly early in their careers, but not suffer from significant economic insecurity, while the opposite might be true for the less educated (Stiglitz et al., 2009). Thus, it is important to note the difference between employment uncertainty, economic insecurity, and income volatility.

\section{MEASURES}

Considering the complexity involved in defining and conceptualising employment uncertainty, as outlined above, this section reviews employment uncertainty measures identified in the fertility literature. It starts with individual objective measures (Sections 3.1-3.4), mixed objective, and subjective measures (Sections 3.5-3.6) before proceeding to individual subjective measures (Sections 3.7-3.9). Finally, it looks at macro-level measures (Section 3.10). Measures are summarised in Table A1 in the Appendix.

\subsection{EMPLOYMENT STATUS}

Numerous studies analyse individuals' or couples' employment status in the context of fertility/childbearing. Baizán (2005) explores the effect of employment status nine months prior to childbirth and differentiates between employed, unemployed, student, or housewife. Additionally, he includes the employment sector (public or private), contract type (stable, temporary, or self-employed), and working hours (full or part-time) collected once per year and assumed to apply consistently over that year. Baizán (2009) further revises this model and includes a time-varying employment status, which is updated monthly. Adsera (2011b) examines women's employment status over the previous seven months and distinguishes between working and unemployed/inactive. Work is further differentiated by creating dummy variables for part-time, public sector, selfemployed, and very short contracts.

Barbieri et al. (2015) create four categories of workers using employment types, comprised of permanent employment, selfemployment, atypical employment, and other non-standard jobs. ${ }^{1}$ They construct this typology using the type of contract for dependent workers (permanent, fixed-term, training contract, seasonal, or off-the-books), manner of self-employment (with employees, without employees, freelancer, or entrepreneur), whether the work was seasonal or occasional, and the standardised four-digit International Standard Classification of Occupation (ISCO) code. ${ }^{2}$ To capture employment uncertainty, the authors create a binary indicator for the transition from an insecure to a secure employment position using the four established employment types, where 0 indicates insecure work (atypical or non-standard) and 1 indicates secure work (permanent or self-employed).

An alternative approach categorises the positional status of a woman in the household by accounting for her partnership status and her partner's employment status. Wood \& Neels (2017) create eleven time-constant ${ }^{3}$ categories: (1) Child in the household, (2) single, (3) married to an employed partner, (4) married to an unemployed partner, (5) married to an inactive partner, (6) married to a partner of unknown status, (7) cohabitating with an employed partner, (8) cohabitating with an unemployed partner, (9) cohabitating with an inactive partner, (10) cohabitating with a partner of unknown status, and (11) other. In addition, they use a time-constant covariant of female employment, distinguishing between (1) employed full-time, (2)

\footnotetext{
1 Atypical employment is defined as a fixed-term contract or pseudo self-employed-performing a job with a self-employed contract in a subordinate position. Non-standard jobs are mainly seasonal or "off-the-books."

2 International Standard Classification of Occupation (ISCO) by the International Labour Organization. Barbieri et al. (2015) use the ISCO-08 framework.

${ }^{3}$ Women's partnership + employment status is measured in 2001. They then use discrete time hazard models to estimate timing of first, second, and third births for 2002-2005.
} 
employed part-time, (3) unemployed, (4) inactive, or (5) other/unknown. This model considers women on maternity leave as being employed full-time.

\subsection{INCOME}

In countries where social benefits have a function similar to employment stability (e.g., Sweden), income can be used as a proxy of objective risk of employment uncertainty. Andersson (2000) examines a ten-year period using a time-varying income measure that includes income from paid work, benefits, and in-kind transfers (including student benefits and unemployment assistance). Andersson distinguishes between three income groups, as well as four non-income earning statuses (student, unemployed, vocational training, or in pension). In a follow-up study, Andersson and Scott (2007) refine this income approach by using employment status and yearly income to stratify persons into eight groups: student, unemployed, welfare, low income (without government income assistance), medium income, high income, top income, and non-response. The authors remark that this income approach is most logical in strong welfare states where students and the unemployed receive sizable benefits that reduce the risk of job loss or career change.

While several studies have used income to explain fertility, others have used income to control for the risk associated with employment uncertainty. Baizán (2005) uses two indicators, the woman's income and her partner's income, to create four income groups: very low (less than 33.3 percent of the national sex-specific median income), low (from 33.3 to less than 66.6 percent), medium (from 66.6 to 90.0 percent), and high (over 90.0 percent). Schmitt (2008) studies relative income within the partnership (substantially lower than that of partner, both incomes are about the same, or own income is higher than that of partner). ${ }^{4}$ The author uses this approach to look into different household types (male breadwinners, equal, female breadwinners) and how they affect each partner's perception of employment uncertainty.

Employment uncertainty from temporary employment may come from the decreased earning potential rather than the contract length (van Wijk et al., 2021). Using income as a mediator, van Wijk et al. analyse how temporary employment affects the timing of first birth. They measure income as the natural log of individual yearly earnings.

\subsection{NUMBER AND DURATION OF JOB SPELLS}

Using retrospective employment histories is an approach to quantify time spent in unemployment (e.g., total number of months spent in unemployment, ratio of years/months spent in paid employment, number of previous job shifts). Özcan et al. (2010) analyse birth outcomes by studying the number of months spent in unemployment, the number of unemployment spells, and the number of prior job shifts. Schmitt (2008) takes a similar approach by adding the number of incidences of long-term employment (spells longer than four months) within the last five years.

Pailhé and Solaz (2012) examine employment uncertainty by creating three indicators to explore both timing of births and completed fertility. The first is a time-varying indicator that looks at employment status in the previous year: long-term employment, short-term employment, unemployment, or homemaker (for women). It is measured at $t$ - 1 to capture the recent experiences of each individual in the labour market. Next, they create a time-varying ratio of years spent in unemployment/short-term employment over permanent employment since union formation. Finally, they include employment status at union formation.

In contrast to measuring unemployment as a count of states or as a ratio, other work attempts to measure more dynamically by combining the number and intensities of unemployment spells into one indicator. Ciganda (2015) uses the notion of a stable

${ }^{4}$ Measured as one third or less of partner's income, within one third, or more than one third and above. 
state $^{5}$ as a desired state, and then uses sequence analysis to generate a unique indicator of time spent in unstable states, ${ }^{6}$ combining previous count and ratio measures.

Busetta et al. (2019) use a similar approach for their Persistent Joblessness Indicator (PJI), which standardises the experience of career joblessness between 0 and 1 . Their indicator focuses on being in or out of paid employment as a binary state. Like Ciganda (2015), they use sequence analysis to combine the number and intensity of joblessness spells. However, the PJI contributes to Ciganda's method by additionally calculating the proximity of years with jobless periods as well as the recentness of joblessness to the observation period. Finally, they factor in local labour market characteristics by controlling for the unemployment experiences of peers.

\subsection{OCCUPATIONAL CLASS}

Some studies use occupational class as a proxy for general economic well-being or vulnerability in the job market. Barbieri et al. (2015) use a time-varying indicator based on the Erikson-Goldthorpe-Portocarero (EGP) classification system. ${ }^{7}$ Bernardi \& Nazio (2005) apply ISCO classifications to occupations, stratifying them into eight groups: service, routine white collar, skilled worker, unskilled worker, unskilled manual worker, self-employed with employees, self-employed without employees, and agricultural worker. The authors consider individuals who are unskilled workers, self-employed, or agricultural workers as being more economically insecure since they generally have lower incomes and less ability to save. They link this to employment uncertainty by also controlling for contract type (permanent contract, fixed-term training contract, other form of fixed-term contract, consulting job, or without a contract) as well as employment status (in education, out of education but not looking for a first job, in search of the first job, unemployed, inactive, and employed).

\subsection{JOB CHARACTERISTICS}

Job-specific aspects might make individuals feel more or less certain about their employment. Because job characteristics beyond contract type and working hours are often more heterogenous, studies use subjective survey questions to overcome interpersonal heterogeneities. Begall and Mills (2011) focus on three distinct job characteristics to capture these differences: The first, perceived work control, is based on the following six features: pace of work, daily organisation of work, power in company policy decisions, requirement to learn new skills, if the job offers variety in tasks and challenges, and tasks are not closely supervised. The second factor is job strain or the feeling that there is never enough time to finish tasks. Finally, work-family conflict comprises the following four aspects: worrying about work problems when not working, feeling too tired after work to enjoy things one would like to do at home, finding the job prevents from spending time with a partner or family, and perceiving that the partner or the family get fed up with the pressures of the respondent's job. They further incorporate a weight based on the importance placed on being able to combine family and work when choosing a job. In a similar vein, Schmitt (2012) includes objective measures of career-oriented time pressure by adding an indicator for overtime worked in order to see how job-related time pressure affects entry into parenthood.

Arguably, the emotions associated with employment uncertainty are not directly capturable. Vignoli et al. (2020b) use subjective well-being (SWB) as a proxy for unobservable job characteristics, positing that SWB is negatively affected by unemployment, tenuous employment, and the distinct characteristics of particular jobs that make people feel unstable. They argue that employment uncertainty may be highly age- and career-specific; part-time or fixed contract work may give younger, less established workers opportunities to be flexible in their careers, temporarily increasing SWB, but that flexibility can turn

\footnotetext{
${ }^{5}$ He distinguishes between the following states: student, military service, full-time employment, self-employed, part-time employment, on leave, helping at home, unemployed, retired, inactive, sick, or other. For men, he defines unemployment and part-time employment as unstable states, while only unemployment is classified as unstable for women. This is because a majority of men reported that being in part-time employment was involuntary, while women may use part-time employment as a way to reconcile career and family duties.

${ }^{6}$ In a hypothetical scenario where two respondents spent the same amount of time unemployed but the first respondent had 10 spells, while the second respondent only had two spells, the first respondent would have an indicator that signifies a higher level of instability.

7 The Goldthorpe Class Scheme is widely used to examine social mobility in industrialised nations and is often referred to in the literature as EGP (Erikson-Goldthorpe-Portocarero) after its three principal founders (Erikson et al., 1979). The scheme classifies workers into several categories based on labour market and work situation.
} 
to insecurity as they age and would like to start a family. The authors use SWB to capture the age when flexible working situations no longer increase SWB but infringe upon it.

\subsection{CAREER MAKING}

Employment uncertainty could be the perception of working in a position below career ambitions (e.g., individuals perceive that they are on the wrong career trajectory with their current employment). While this might directly relate to income, it can also concern a position's prestige and the perception of advancement opportunities. Schmitt (2012) examines educational qualifications and first job characteristics to test if not having a perceived sufficiently prestigious job affects fertility outcomes. He creates an index to see if individuals were underqualified, properly qualified, or overqualified for their first position. Establishing a level of employment stability often starts at the relative level of first employment, and individual sense of stability depends on if individuals believe their qualifications match the job prestige. In this case, subjective perception is derived from objective measures and not directly asked.

\subsection{SUBJECTIVE PERCEPTIONS OF SECURITY}

The most direct way to capture forward-looking subjective perceptions of employment uncertainty is to ask job security questions in surveys. Golsch (2003) includes perception of job satisfaction ${ }^{8}$ as a way to assess job security. Hanappi et al. (2017) expand on this by explicitly asking about job security ${ }^{9}$ to evaluate the risk of becoming unemployed in the following twelve months. They create an indicator to see if perceived insecurity rose or declined between waves as well as an indicator for changes to or from fixed-term contracts. They add an indicator for change in job security by the respondent's partner.

Unemployment can be a form of certainty (i.e., you know you do not have a job). Individuals who have a high probability of changing states (employed to unemployed or vice versa) face the highest perceived levels of uncertainty. Bhaumik \& Nugent (2011) utilise two questions to assess perceptions of job security: One for employed persons about the risk of losing their job (very concerned, somewhat concerned, or not concerned at all) and one for unemployed individuals about the ease of finding employment (easy, difficult, or almost impossible). They combine these two items to create a 6-point scale, with 1 being "employed and secure" and 6 being "unemployed with a low perceived chance of finding a job." The logic is that the middle scores, 3 or $4,{ }^{10}$ are where individuals face the most employment uncertainty.

Fahlén and Oláh (2018) combine perceived job security with perceived income security to more comprehensively capture the subjective threat of insecurity through self-evaluation questions about respondents' employment circumstances and economic resources. Perceived job security is evaluated with the statement "[m]y job is secure,"11 while perceived income security is evaluated according to the perception of household financial resources. ${ }^{12}$. Along with income, van Wijk et al. (2021) use two types of subjective forms of job security ${ }^{13}$ to mediate the effect of temporary contracts. Both variables are measured as dummies: 1 if the person perceives job insecurity and 0 if not.

Various studies have use perceptions of financial security as a measure of general economic uncertainty (Kreyenfeld, 2005, 2016; Testa \& Basten, 2014). However, since getting pregnant carries significant financial costs, there is an endogenous relationship to the answer individuals give in the survey and their likelihood of getting pregnant in the next year. Hofmann

\footnotetext{
${ }^{8}$ From the Spanish European Community Household Panel (ECHP): "How satisfied are you with your present job or business in terms of earnings, hours of work, working conditions, etc."

9 "Would you say that your job is very secure, quite secure, a bit insecure or very insecure?"

103 is coded as individuals who are employed but "very concerned" about losing their job, while 4 is coded as individuals who are unemployed who can "easily" find employment.

11 On a 5-point Likert scale

12 "How do you feel about your household's income nowadays?" The possible answers are: Living comfortably, coping, finding it difficult, or finding it very difficult.

13 If individuals perceive that they are at risk of losing their job (cognitive job insecurity) and if they worry about losing their job (affective job insecurity).
} 
and Hohmeyer (2013) examine perceived economic uncertainty using survey data. ${ }^{14}$ They then use an instrumental variable approach with survey waves before and after an announced German unemployment benefit reform to remove the endogeneity related to subjective perceptions of financial security and fertility behaviours. They additionally stratify the sample into household types: dual-income, male main breadwinner (women work at least part-time), and specialised male breadwinner (women are non-working) in order to study how perceived financial stress affects individuals within the financial context that fertility decisions are made. While this method does not directly test for employment uncertainty, the authors relate household type and financial stress directly to employment situation.

\subsection{PERCEPTION OF RESILIENCE}

Uncertainty can be seen as not only the fear of losing current employment, but also as the fear of not being able to replace one quickly. Gatta et al. (2021) incorporate the perception of job security (likelihood to still have a job in the next six months) with an additional theoretical idea of resilience, captured by the perceived ability to find a new job in case of job loss. They control for the subjective differences in perception of resilience with an additional question about the individual's risk aversion.

\subsection{EXPERIMENTAL METHODS}

To look how regional and national level attitudes towards present and future uncertainty influence individuals' notion of uncertainty, Guetto et al. (2020) expand their narrative framework into an experimental framework using short-term fertility intentions, splitting the sample into five groups. In a follow-up interview a few months later, each respondent received one of several fabricated news stories about the COVID-19 pandemic, describing various lengths of return to normality following a lockdown. The goal was to examine if consumed media (or communal perceptions of economic/employment uncertainty) affects individual levels of uncertainty about fertility intentions. This experimental approach is innovative and its larger application for measuring the effect of communal perceptions of uncertainty still needs to be worked out in the field.

\subsection{MACRO MEASURES}

The most commonly used macro-level measures for employment uncertainty are national and local unemployment rates. Unemployment rates can signify the capacity to find or change employment. Adsera (2011a) applies twelve-month backdated female unemployment rates as well as the national long-term unemployment rate interacted with the female labour force participation rate. Kravdal (2002) uses the regional unemployment rate to see how regional and sector-specific unemployment affects fertility behaviour, differentiating between agricultural, manufacturing, and service sectors. Pailhé and Solaz (2012) use gender-specific regional unemployment rates as a proxy for the individual perceived risk of unemployment. Fahlén and Oláh (2018) use unemployment rates plus a measure of employment protection legislation (as measured by the OECD) that combines individual and collective termination and temporary employment legislation. ${ }^{15}$

Contractual agreements (as discussed in Section 3.1) can negatively or positively affect employment uncertainty. One the one hand, people who are forced to accept part-time work might feel more uncertain about their employment than those who do so willingly. On the other hand, part-time work allows mothers to remain in the labour force. Therefore, the share of contractual agreements can be a proxy measure of society-wide employment uncertainty. The share of workers in part-time work varies significantly across high-income countries (OECD, 2021). This also applies to the percentage of workers employed in the public sector (which greatly reduces employment uncertainty) or in self-employment (generally associated with increased employment uncertainty). Adsera (2011a) uses the share of public sector, self-employment, and part-time employment to look at the effect of contractual agreements on birth outcomes across countries. Part-time employment is interacted with female

\footnotetext{
${ }^{14}$ From the German Socioeconomic Panel “What is your attitude towards your own economic situation?" with the options of: Very concerned, somewhat concerned, or not concerned at all.

15 The OECD uses 24 measures of the strictness of employment protection for both individuals and collective dismissals to create an indicator of the level of legal employment protection in each country. Specific details can be found here:

https://www.oecd.org/els/emp/oecdindicatorsofemploymentprotection.htm
} 
labour force participation rates to evaluate the relative importance of part-time work as a strategy for reconciling work and family.

\section{CONSIDERATIONS FOR MEASURE CHOICE}

Employment uncertainty is a complex theoretical topic involving several layers and temporal aspects. No single measure completely captures the entire scope of uncertainty. Objective measures focus on normative individual employment situations, while subjective measures aim to directly describe feelings and perceptions of employment uncertainty. There are advantages and disadvantages to selecting objective and/or subjective measures, which researchers should keep in mind when designing their study. Not recognising their specific limitations can lead researchers to overstating their findings.

\subsection{OBJECTIVE MEASURES}

The advantage to using objective measures is their ease. Many of the measures have largely universal definitions and are available from a variety of data sources (e.g., registries, censuses, or surveys). National governments and/or private entities within countries (e.g., insurance companies) often collect basic demographic details and employment status on a monthly or weekly basis, making large, reliable datasets available. Furthermore, objective measures have many advantages for crosscountry comparisons. Finally, objective measures are perceived as being more theoretically straightforward. Hence, it is the universality, availability, comparability, and relative straightforwardness that make them attractive.

Objective measures are often preferred because they avoid the pitfalls of interpersonal subjectivity. However, for employment uncertainty, they require that the researcher makes the assumption that the drivers of expectation formation are past and present experiences (Leach et al., 2013). The rationale is that past experiences create adaptive expectations as well as structural constraints. However, since uncertainty is inherently forward-looking, associations between fertility outcomes and objective measures may confuse the direction of the effect (Bloom, 2014).

The most common objective measure used for measuring employment uncertainty is employment status. Yet, there is no precise approach for properly measuring the nuanced difference between types of employment status when deciding which are uncertain (e.g., difference between full-time and part-time employment, difference between forced and elected inactivity, or self-employment as a choice or an alternative to a bad job market). Almost all other objective measures of employment uncertainty build upon how researchers demarcate employment statuses as either certain or uncertain. Therefore, a study's conceptualisation of employment status matters.

Some studies use recategorisation to investigate the nuances in employment status. The process generally starts by theoretically defining potential forms of employment status, noting specific situations and then categorising them into new groups (e.g., involuntary part-time employment, self-employment in a dependant situation, or "non-traditional" employment). However, different studies have placed some employment types on either side of the uncertainty spectrum. Self-employment, for instance, is understudied and is often categorised as either secure or insecure employment without a significant conceptual explanation as to why (Bozzon \& Murgia, 2021). The share and nature of self-employment varies significantly between different welfare labour regimes (Hatfield, 2015). For example, in many Southern European countries, individuals resort to selfemployment as an alternative to poor employment opportunities, which not usually the case in other European countries (Barbieri et al., 2015). Thus, categorising employment status as secure or insecure in cross-country comparison can be even trickier as each labour market dictates the employment circumstances of its participants.

In spite of efforts to make better categories of insecure employment according to specific employment circumstances, there are theoretical issues that employment status does not address. It is impossible to know if two individuals with the same employment history both experience employment uncertainty. Again, using employment status as a proxy for uncertainty becomes significantly more difficult in cross-country comparisons where the share of employment relationships changes with the economic situation and labour laws (Pfau-Effinger, 2019). The share of employment situations within a country also changes 
over time (e.g., the number of part-time workers can fluctuate with changes in employment regulations and macro-economic influences). Additionally, new forms of employment have emerged in recent years (e.g., gig work ${ }^{16}$ ), whose effect on fertility remains unknown (Healy et al., 2017). Work location is also changing (e.g., home office), which has the potential to impact fertility behaviour.

Another common issue is the gendered differences in employment status. Many women - and increasingly men - leave the labour market to take on family care responsibilities. Equating an inactive status to an unemployed one may miscategorise employment uncertainty, especially when considering fertility intentions and outcomes. A frequent solution is to categorise inactive women as secure, but inactive men as insecure (Ciganda, 2015). This assumption may simplify the analysis, but ignores significant research suggesting a large amount of heterogeneity in employment choices (Vitali et al., 2009).

Objective macro measures are particularly useful for cross-country comparisons where institutional and cultural differences can make individual measures difficult to compare (Fesseau et al., 2013). Macro measures assume that individuals face similar risk across the sample area. This assumption can be mitigated by using demographic-specific measures (e.g., women's unemployment rate). It can be further improved upon by using smaller regions, although this tends to both decreases data availability and adds complexity (Campisi et al., 2020).

Finally, the decision to select a relative or absolute measure needs to be determined by the research question. Relative counts allow for easier comparison across time and space. They are particularly useful for observing diverging trends between specific groups but can obscure changes in level (e.g., when all individuals experience downward or upward movements) because they remain relatively the same. Absolute measures enable examining the scope of an issue but can understate perceptions which are often based on relative understandings (Easterlin, 1973). For employment uncertainty, it matters how much time an individual has spent experiencing unstable unemployment, but evidence also shows that it is important to evaluate how common employment uncertainty is among peers (Hofmann et al., 2017). Previously, this time-varying societal perception of economic insecurity has been controlled for with macro measures like national or regional unemployment rate, sex-specific unemployment rate, or consumer confidence index. However, there is a growing acknowledgement that more focus should be given to how macro uncertainty affects the relative perception of one's labour market position (Vignoli et al., 2020a).

\subsection{SUBJECTIVE MEASURES}

When evaluating employment uncertainty, subjective measures have the advantage of directly examining which anxieties cause the individual to feel uncertain about their job. However, these measures have several disadvantages. For example, subjective measures are only as applicable as the survey question's proper use. Survey questions are often asked with a specific model in mind (e.g., Theory of Planned Behaviour) (Brehm \& Schneider, 2019). Therefore, the questions' wording may not fit into the researcher's conceptualisation of employment uncertainty. Subjective questions can also be biased by post-hoc rationalisation, in which individuals state that detrimental employment circumstances led to more positive outcomes. This psychological effect positively biases subjective questions, particularly when the main cause of employment uncertainty has already occurred (Stewart \& Hull, 1992). Furthermore, subjective measures are sensitive to recent events, respondents' immediate circumstances, and cultural and linguistic bias (Jahedi \& Méndez, 2014). Even in the same cultural context, interpersonal differences like optimism or pessimism complicate comparing perceived levels of uncertainty. Studies often combine subjective measures with objective ones to account for the relative effect of interpersonal difference (Kreyenfeld, 2016; Liefbroer, 2005). Additionally, some longitudinal statistical techniques examine latent features of individuals across time that help reduce interpersonal differences (Bollen \& Long, 1993). Survey frequency dictates the accuracy of the subjective measures (Kahneman \& Krueger, 2006): Greater intervals between survey waves may miss periods of uncertainty, since employment uncertainty is often short-lived but highly consequential. Finally, studies that use both subjective and objective measures often overestimate the effect of the explanatory variables (Jahedi \& Mendez, 2014). Objective measures are preferable when subjective and objective measures are highly correlated, as they are less like to suffer from bias (Ibid.).

\footnotetext{
${ }^{16} \mathrm{Gig}$ work is most easily defined as work contingent on some external demand (Watson et al., 2021). Workers tend to only have loose working relationships with the employer and compensation is based on one specific performance indicator. It is common for online platform workers, independent contractors, freelancers, on-call workers, and zero-hour contracts.
} 


\section{CONCLUSION}

Studies that use objective measures, subjective measures, or a mixture of the two have concluded that employment uncertainty negatively impacts both the timing and total number of births. Nevertheless, the results from these studies paint a heterogeneous picture of the size and significance of the effect. What is clear from the results of the empirical work is that employment uncertainty affects fertility differently between socioeconomic groups, genders, parities, and countries.

Having permanent, full-time employment-particularly for men-increases fertility (Pailhé \& Solaz, 2012). However, studies that do not include income and partnership risk overestimating the effect of employment uncertainty on fertility (Alderotti et al., 2021). There appears to be strong evidence that the income effect reduces fertility for both men and women, specifically with fixed-term contracts (Kohler et al., 2002; van Wijk et al., 2021). Men appear to be to be more uniformly affected by employment uncertainty, likely due to their attractiveness on the marriage market (Kalmijn, 2011; Oppenheimer, 1988). By contrast, women show much more heterogeneity. There is evidence that women with either high or low incomes have an increased risk of child birth (Baizán, 2005). However, that may not be true for lower educated women or those living in Southern and Eastern Europe (Adsera, 2011a). The heterogenous effects of employment uncertainty extend to different ethnic, immigrant, and occupational groups (Barbieri et al., 2015; Dupray \& Pailhé, 2018; Kulu \& Hannemann, 2016; Wood \& Neels, 2017). This effect appears to be different for first birth than higher parity births (Andersson, 2000), although few papers study both. Higher subjective perceptions of employment uncertainty reduce fertility (Fahlén \& Oláh, 2018; Hanappi et al., 2017). Both objective and subjective negative job characteristic (e.g., job-related stress) seem to impact fertility (Begall \& Mills, 2011). All studies listed in Section 3 found negative effects of employment uncertainty on fertility for some groups.

The more heterogenous results for women may be due to the preference towards family life or children as an alternative to participating in the labour market (Hakim, 2003). Using subjective questions of work and family preferences to support the process of categorising uncertain employment statuses may help reduce errors from false categorisation. As far as the author is aware, no research has yet been able to comprehensively capture the effect of voluntary versus involuntary unemployment/inactiveness. Future research should consider the level in which most fertility decisions are made: not exclusively by the individual but rather at the dyadic (partner) level, since individuals consider both their own and their partner's employment situation when making fertility decisions.

Both fertility and employment uncertainty are age-specific (Adsera, 2011a). The literature is not clear as to whether the temporal proximity of employment uncertainty to the intended timing of the birth event has a significant effect. Since employment is interlinked with other life-course domains like partnership, housing and health, observing causal links is not always straightforward (Huinink \& Kohli, 2014). Early-career employment uncertainty may have a ripple effect on precursory life course domains, delaying or stunting the transition to parenthood (Billari, 2001). Employment uncertainty is also likely to permeate other life domains, making it more complex to determine the directionality of life-course domain uncertainty. The effect that the uncertainty of other life domains has on employment uncertainty continues to be an area for exploration.

Limited studies examine sector, cultural, or country-specific tolerance for uncertainty. Tolerance for uncertainty may be age or education-specific. For example, the highly educated may take longer to enter the labour market and accept less stable employment positions in order to gain human and social capital (Perrier, 2013). Lower educated individuals may unwillingly have to accept jobs with unstable working hours or short-term contracts (Heinz, 2009). Thus, while uncertainty is often considered as a non-favourable situation, employment uncertainty may be tolerated or even desired at specific points in the career trajectory (Kalleberg, 2009; Vignoli et al., 2020b). Hence, the question is not only if individuals face uncertainty, but if they have the (perceived) capacity to escape it (Gatta et al., 2021; Green et al., 2000). Future research needs to confront the likelihood that uncertainty is not necessarily a negative part of an individual's life. Rather, there seems to be two key aspects: the capacity and perception to escape it when desired. Thus, there are both objective questions (e.g., what defines the capacity to escape uncertain employment) and subjective ones (e.g., how to measure a person's perception of their risk of being stuck in uncertain employment). Researchers should not take a naïve approach in assuming employment uncertainty is inherently negative, but instead find ways to examine how individuals deal with it. 


\section{REFERENCES}

Adsera, A. (2004). Changing fertility rates in developed countries. The impact of labor market institutions. Journal of Population Economics, 17(1), 17-43.

Adsera, A. (2011a). Where are the babies? Labor market conditions and fertility in Europe. European Journal of Population/Revue Européenne de Démographie, 27(1), 1-32.

Adsera, A. (2011b). The Interplay of Employment Uncertainty and Education in explaining Second Births in Europe. Demographic Research, 25(16), 513-544.

Alderotti, G., Vignoli, D., Baccini, M., \& Matysiak, A. (2021). Employment Instability and Fertility in Europe: A MetaAnalysis. Demography, 58(3), 871-900.

Anderson, C. J., \& Pontusson, J. (2007). Workers, worries and welfare states: Social protection and job insecurity in 15 OECD countries. European Journal of Political Research, 46(2), 211-235.

Andersson, G. (2000). The impact of labour-force participation on childbearing behaviour: Pro-cyclical fertility in Sweden during the 1980s and the 1990s. European Journal of Population/Revue Européenne de Démographie, 16(4), $293-333$.

Andersson, G., \& Scott, K. (2007). Childbearing dynamics of couples in a universalistic welfare state: The role of labor-market status, country of origin, and gender. Demographic Research, 17, 897-938.

Baizán, P. (2005). The impact of labour market status on second and higher-order births. A comparative study of Denmark, Italy, Spain and United Kingdom. http://repositori.upf.edu/handle/10230/267

Baizán, P. (2009). Regional child care availability and fertility decisions in Spain. Demographic Research, 21, 803-842.

Barbieri, P., Bozzon, R., Scherer, S., Grotti, R., \& Lugo, M. (2015). The rise of a Latin model? Family and fertility consequences of employment instability in Italy and Spain. European Societies, 17(4), 423-446.

Beck, U. (1992). Risk society: Towards a New Modernity. Sage Publications.

Becker, G. S. (1960). An Economic Analysis of Fertility, Demographic and economic change in developed countries: A conference of the Universities. National Bureau Commitee for Economic Research, 209.

Beckert, J. (2016). Imagined futures: Fictional expectations and capitalist dynamics. Harvard University Press.

Begall, K., \& Mills, M. (2011). The impact of subjective work control, job strain and work-family conflict on fertility intentions: A European comparison. European Journal of Population/Revue Européenne de Démographie, $27(4), 433$.

Bernardi, F., \& Nazio, T. (2005). Globalization and the transition to adulthood in Italy. Globalization, Uncertainty and Youth in Society: The Losers in a Globalizing World, 359-385.

Bernardi, L., Huinink, J., \& Settersten Jr, R. A. (2019). The life course cube: A tool for studying lives. Advances in Life Course Research, 41, 100258.

Bernardi, L., Mynarska, M., \& Rossier, C. (2015). Uncertain, changing and situated fertility intentions. In Reproductive decisionmaking in a macro-micro perspective (pp. 113-139). Springer.

Bhaumik, S. K., \& Nugent, J. B. (2011). Real options and demographic decisions: Empirical evidence from East and West Germany. Applied Economics, 43(21), 2739-2749. 
Billari, F. C. (2001). The Analysis of Early Life Course Complex Descriptions of the Transition to Adulthood. Journal of Population Research, 18(2), 119-142.

Bloom, N. (2014). Fluctuations in uncertainty. Journal of Economic Perspectives, 28(2), 153-76.

Blossfeld, H.-P., Klijzing, E., Mills, M., \& Kurz, K. (2006). Globalization, uncertainty and youth in society: The losers in a globalizing world. Routledge.

Bollen, K. A., \& Long, J. S. (1993). Testing Structural Equation Models. SAGE.

Bozzon, R., \& Murgia, A. (2021). Work-family conflict in Europe. A focus on the heterogeneity of self-employment. Community, Work \& Family, 24(1), 93-113.

Brehm, U., \& Schneider, N. F. (2019). Towards a Comprehensive Understanding of Fertility: The Model of Dyadic Pathways. Comparative Population Studies, 44. https://doi.org/10.12765/CPoS-2019-01

Busetta, A., Mendola, D., \& Vignoli, D. (2019). Persistent joblessness and fertility intentions. Demographic Research, 40, 185218.

Campisi, N., Kulu, H., Mikolai, J., Klüsener, S., \& Myrskylä, M. (2020). Spatial variation in fertility across Europe: Patterns and determinants. Population, Space and Place, 26(4), e2308.

Cheng, G. H.-L., \& Chan, D. K.-S. (2008). Who Suffers More from Job Insecurity? A Meta-Analytic Review. Applied Psychology, 57(2), 272-303.

Ciganda, D. (2015). Unstable work histories and fertility in France: An adaptation of sequence complexity measures to employment trajectories. Demographic Research, 32, 843-876.

Comolli, C. L. (2017). The fertility response to the Great Recession in Europe and the United States: Structural economic conditions and perceived economic uncertainty. Demographic Research, 36, 1549-1600.

Davidson, P. (1996). Reality and economic theory. Journal of Post Keynesian Economics, 18(4), 479-508.

Dupray, A., \& Pailhé, A. (2018). Does employment uncertainty particularly impact fertility of children of North African immigrants in France? A gender perspective. Journal of Ethnic and Migration Studies, 44(3), 401-424.

Easterlin, R. A. (1973). Relative economic status and the American fertility swing. Family Economic Behavior, 170-223.

Elster, J. (2009). Excessive ambitions. Capitalism and Society, 4(2).

Erikson, R., Goldthorpe, J. H., \& Portocarero, L. (1979). Intergenerational class mobility in three Western European societies: England, France and Sweden. The British Journal of Sociology, 30(4), 415-441.

Esser, I., \& Olsen, K. M. (2012). Perceived Job Quality: Autonomy and Job Security within a Multi-Level Framework. European Sociological Review, 28(4), 443-454.

Fahlén, S. (2013). Capabilities and Childbearing Intentions in Europe: The association between work-family reconciliation policies, economic uncertainties and women's fertility plans. European Societies, 15(5), 639-662.

Fahlén, S., \& Oláh, L. S. (2018). Economic uncertainty and first-birth intentions in Europe. Demographic Research, 39, 795-834.

Fesseau, M., Wolff, F., \& Mattonetti, M. L. (2013). A Cross-country Comparison of Household Income, Consumption and Wealth between Micro Sources and National Accounts Aggregates. 
Gatta, A., Mattioli, F., Mencarini, L., \& Vignoli, D. (2021). Employment uncertainty and fertility intentions: Stability or resilience? Population Studies, 1-20.

Gauthier, A. H. (2007). The impact of family policies on fertility in industrialized countries: A review of the literature. Population Research and Policy Review, 26(3), 323-346.

Gebel, M., \& Giesecke, J. (2011). Labor Market Flexibility and Inequality: The Changing Skill-Based Temporary Employment and Unemployment Risks in Europe. Social Forces, 90(1), 17-39.

Golsch, K. (2003). Employment flexibility in Spain and its impact on transitions to adulthood. Work, Employment and Society, 17(4), 691-718.

Green, F., Felstead, A., \& Burchell, B. (2000). Job insecurity and the difficulty of regaining employment: An empirical study of unemployment expectations. Oxford Bulletin of Economics and Statistics, 62, 855-883.

Guetto, R., Bazzani, G., \& Vignoli, D. (2020). Narratives of the future shape fertility in uncertain times. Evidence from the COVID-19 pandemic. In Econometrics Working Papers Archive (2020_11; Econometrics Working Papers Archive). Universita' degli Studi di Firenze, Dipartimento di Statistica, Informatica, Applicazioni “G. Parenti." https://ideas.repec.org/p/fir/econom/wp2020_11.html

Hacker, J. S. (2019). The great risk shift: The new economic insecurity and the decline of the American dream. Oxford University Press.

Hakim, C. (2003). A new approach to explaining fertility patterns: Preference theory. Population and Development Review, 29(3), 349-374.

Hanappi, D., Ryser, V.-A., Bernardi, L., \& Le Goff, J.-M. (2017). Changes in employment uncertainty and the fertility intention-realization link: An analysis based on the Swiss household panel. European Journal of Population, 33(3), 381407.

Hatfield, I. (2015). Self-employment in Europe (No. 4). IPPR. https://www.ippr.org/files/publications/pdf/self-employmentEurope_Jan2015.pdf

Healy, J., Nicholson, D., \& Pekarek, A. (2017). Should we take the gig economy seriously? Labour E Industry: A Journal of the Social and Economic Relations of Work, 27(3), 232-248.

Heinz, W. R. (2009). Youth transitions in an age of uncertainty. In Handbook of youth and young adulthood (pp. 19-29). Routledge.

Hellstrand, J., Nisén, J., Miranda, V., Fallesen, P., Dommermuth, L., \& Myrskylä, M. (2020). Not just later, but fewer: Novel trends in cohort fertility in the Nordic countries. Max Plank Demographic Research Institute, Rostock, MPIDR-Working Paper, 7.

Hofmann, B., \& Hohmeyer, K. (2013). Perceived economic uncertainty and fertility: Evidence from a labor market reform. Journal of Marriage and Family, 75(2), 503-521.

Hofmann, B., Kreyenfeld, M., \& Uhlendorff, A. (2017). Job Displacement and First Birth Over the Business Cycle. Demography, 54(3), 933-959.

Hofmeister, H., Mills, M., \& Blossfeld, H.-P. (2006). Globalization, Uncertainty and Women's MidCareer Life Courses: A Theoretical Framework. Globalization, Uncertainty and Women's Careers: An International Comparison, 3-31.

Huinink, J., \& Kohli, M. (2014). A life-course approach to fertility. Demographic Research, 30, 1293-1326. 
Iceland, J. (2005). Measuring Poverty: Theoretical and Empirical Considerations. Measurement: Interdisciplinary Research and Perspectives, 3(4), 199-235.

Jahedi, S., \& Méndez, F. (2014). On the advantages and disadvantages of subjective measures. Journal of Economic Behavior $\mathcal{E}$ Organization, 98, 97-114.

Kahneman, D., \& Krueger, A. B. (2006). Developments in the Measurement of Subjective Well-Being. Journal of Economic Perspectives, 20(1), 3-24.

Kalleberg, A. L. (2009). Precarious work, insecure workers: Employment relations in transition. American Sociological Review, $74(1), 1-22$.

Kalmijn, M. (2011). The Influence of Men's Income and Employment on Marriage and Cohabitation: Testing Oppenheimer's Theory in Europe. European Journal of Population / Revue Européenne de Démographie, 27(3), 269-293.

Kohler, H.-P., Billari, F. C., \& Ortega, J. A. (2002). The emergence of lowest-low fertility in Europe during the 1990s. Population and Development Review, 28(4), 641-680.

Kravdal, Ø. (2002). The impact of individual and aggregate unemployment on fertility in Norway. Demographic Research, 6 , 263-294.

Kreyenfeld, M. (2005). Economic uncertainty and fertility postponement-Evidence from German panel data. MPIDR Working Paper 2005.

Kreyenfeld, M. (2016). Economic uncertainty and fertility. In Social Demography Forschung an der Schnittstelle von Soziologie und Demografie (pp. 59-80). Springer.

Kreyenfeld, M., Andersson, G., \& Pailhé, A. (2012). Economic uncertainty and family dynamics in Europe: Introduction. Demographic Research, 27, 835-852.

Kulu, H., \& Hannemann, T. (2016). Why does fertility remain high among certain UK-born ethnic minority women? Demographic Research, 35, 1441-1488.

Leach, D., Hagger-Johnson, G., Doerner, N., Wall, T., Turner, N., Dawson, J., \& Grote, G. (2013). Developing a measure of work uncertainty. Journal of Occupational and Organizational Psychology, 86(1), 85-99.

Liefbroer, A. C. (2005). The impact of perceived costs and rewards of childbearing on entry into parenthood: Evidence from a panel study. European Journal of Population/Revue Européenne de Démographie, 21(4), 367-391.

Liefbroer, A. C., \& Zoutewelle-Terovan, M. (2021). Social Background and the Demographic Life Course: Cross-National Comparisons. Springer Nature.

Matysiak, A., Sobotka, T., \& Vignoli, D. (2020). The Great Recession and fertility in Europe: A sub-national analysis. European Journal of Population, 1-36.

Mayer, K. U. (2009). New Directions in Life Course Research. Annual Review of Sociology, 35(1), 413-433.

Mills, M., \& Blossfeld, H.-P. (2003). Globalization, uncertainty and changes in early life courses. Zeitschrift Für Erziehungswissenschaft, 6(2), 188-218.

OECD. (2021). Employment-Temporary employment. http://data.oecd.org/emp/temporary-employment.htm

Oppenheimer, V. K. (1988). A theory of marriage timing. American Journal of Sociology, 94(3), 563-591. 
Özcan, B., Mayer, K. U., \& Luedicke, J. (2010). The impact of unemployment on the transition to parenthood. Demographic Research, 23, 807-846.

Pailhé, A., \& Solaz, A. (2012). The influence of employment uncertainty on childbearing in France: A tempo or quantum effect? Demographic Research, 26, 1-40.

Perrier, M. (2013). No right time: The significance of reproductive timing for younger and older mothers' moralities. The Sociological Review, 61(1), 69-87.

Peters, J. (2008). Labour market deregulation and the decline of labour power in North America and Western Europe. Policy and Society, 27(1), 83-98.

Pfau-Effinger, B. (2019). Welfare regimes and the gender division of labour. In Working Europe (pp. 69-96). Routledge.

Richiardi, M. G., \& He, Z. (2019). Measuring economic insecurity: A review of the literature. mimeo, ISER, University of Essex.

Schmitt, C. (2008). Gender-Specific Effects of Unemployment on Family Formation: A Cross-National Perspective. SSRN Electronic Journal.

Schmitt, C. (2012). Labour market integration, occupational uncertainties, and fertility choices in Germany and the UK. Demographic Research, 26, 253-292.

Stewart, W. P., \& Hull, R. B. (1992). Satisfaction of what? Post hoc versus real-time construct validity. Leisure Sciences, 14(3), 195-209.

Stiglitz, J., Sen, A., \& Fitoussi, J.-P. (2009). The measurement of economic performance and social progress revisited. Reflections and Overview. Commission on the Measurement of Economic Performance and Social Progress, Paris.

Sverke, M., Hellgren, J., \& Näswall, K. (2002). No security: A meta-analysis and review of job insecurity and its consequences. Journal of Occupational Health Psychology, 7(3), 242.

Testa, M. R., \& Basten, S. (2014). Certainty of meeting fertility intentions declines in Europe during the 'Great Recession.' Demographic Research, 31, 687-734.

Testa, M. R., \& Toulemon, L. (2006). Family formation in France: Individual preferences and subsequent outcomes. Vienna Yearbook of Population Research, 41-75.

Trevor-Roberts, E. (2006). Are you sure? The role of uncertainty in career. Journal of Employment Counseling, 43(3), 98-116.

van Wijk, D. C., de Valk, H. A. G., \& Liefbroer, A. C. (2021). Temporary Employment and Family Formation: An Income or Insecurity Effect? European Sociological Review, 37(4), 641-658.

Vignoli, D., Bazzani, G., Guetto, R., Minello, A., \& Pirani, E. (2020a). Uncertainty and Narratives of the Future: A Theoretical Framework for Contemporary Fertility. In R. Schoen (Ed.), Analyzing Contemporary Fertility (Vol. 51, pp. 25-47). Springer International Publishing.

Vignoli, D., Mencarini, L., \& Alderotti, G. (2020b). Is the Effect of Job Uncertainty on Fertility Intentions Channeled by Subjective Well-Being? Advances in Life Course Research, 100343.

Vitali, A., Billari, F. C., Prskawetz, A., \& Testa, M. R. (2009). Preference theory and low fertility: A comparative perspective. European Journal of Population/Revue Européenne de Démographie, 25(4), 413. 
Watson, G. P., Kistler, L. D., Graham, B. A., \& Sinclair, R. R. (2021). Looking at the Gig Picture: Defining Gig Work and Explaining Profile Differences in Gig Workers' Job Demands and Resources. Group E Organization Management, 46(2), 327-361.

Wood, J., \& Neels, K. (2017). First a job, then a child? Subgroup variation in women's employment-fertility link. Advances in Life Course Research, 33, 38-52. 


\section{APPENDIX}

TABLE A1: LIST OF SOURCES AND MEASURES OF EMPLOYMENT UNCERTAINTY

\begin{tabular}{|c|c|c|c|c|c|c|c|c|}
\hline Paper & Measure & Sex & $\begin{array}{l}\text { Parity/ } \\
\text { Behaviour }\end{array}$ & Country & Backdate & $\begin{array}{l}\text { Obj./ } \\
\text { Subj. }\end{array}$ & $\begin{array}{l}\text { Micro/ } \\
\text { Macro }\end{array}$ & $\begin{array}{c}\text { Abs./ } \\
\text { Rel. }\end{array}$ \\
\hline $\begin{array}{l}\text { Adsera } \\
\text { (2011a) }\end{array}$ & $\begin{array}{l}\text { Macro: Female unemployment rate, national } \\
\text { log-term unemployment rate } \\
\text { Share of public sector, self-employment, or } \\
\text { part-time worker } \\
\text { Interacted with female labour force } \\
\text { participation rate }\end{array}$ & $\mathbf{F}$ & Second & Multiple & 12 months & Obj. & Macro & $\begin{array}{l}\text { Abs. } \\
\text { Rel. }\end{array}$ \\
\hline $\begin{array}{l}\text { Adsera } \\
(2011 b)\end{array}$ & $\begin{array}{l}\text { Employment status: Working or } \\
\text { unemployed/inactive }\end{array}$ & $\mathbf{F}$ & $\begin{array}{l}\text { Second } \\
\text { Third }\end{array}$ & Multiple & 7 months & Obj. & Micro & Abs. \\
\hline $\begin{array}{l}\text { Andersson } \\
(2000)\end{array}$ & $\begin{array}{l}\text { Income: } 3 \text { income groups }+4 \text { non-income } \\
\text { earning groups }\end{array}$ & $\mathbf{F}$ & $\begin{array}{l}\text { First } \\
\text { Second } \\
\text { Third }\end{array}$ & Sweden & Previous year's info & Obj. & Micro & $\begin{array}{l}\text { Abs. } \\
\& \\
\text { Rel. }\end{array}$ \\
\hline $\begin{array}{l}\text { Andersson } \\
\& \text { Scott } \\
(2007) \\
\end{array}$ & Income: 8 income and benefit groups & B & $\begin{array}{l}\text { Second } \\
\text { Third }\end{array}$ & Sweden & Previous year's info & Obj. & Micro & $\begin{array}{l}\text { Abs. } \\
\& \\
\text { Rel. }\end{array}$ \\
\hline $\begin{array}{l}\text { Baizán } \\
\text { (2005) }\end{array}$ & $\begin{array}{l}\text { Employment status: Employed, unemployed, } \\
\text { student, or housewife; Public/private sector; } \\
\text { Permanent, temporary, or self-employed; } \\
\text { Full/part-time }\end{array}$ & $\mathbf{F}$ & Second+ & $\begin{array}{l}\text { Denmark } \\
\text { Italy } \\
\text { Spain } \\
\text { UK }\end{array}$ & 9 months & Obj. & Micro & Abs. \\
\hline- & $\begin{array}{l}\text { Income: } 4 \text { income groups taking into account } \\
\text { woman's and partner's income }\end{array}$ & - & - & - & - & Obj. & Micro & Rel. \\
\hline $\begin{array}{l}\text { Baizán } \\
(2009)\end{array}$ & $\begin{array}{l}\text { Employment status: Same variables as in Baizán } \\
\text { (2005), but using time-varying variables }\end{array}$ & $\mathbf{F}$ & $\begin{array}{l}\text { First } \\
\text { Second+ }\end{array}$ & Spain & 9 months & Obj. & Micro & Abs. \\
\hline
\end{tabular}


TABLE A1 (CONTINUED): LIST OF SOURCES AND MEASURES OF EMPLOYMENT UNCERTAINTY

\begin{tabular}{|c|c|c|c|c|c|c|c|c|}
\hline Paper & Measure & Sex & $\begin{array}{c}\text { Parity/ } \\
\text { Behaviour }\end{array}$ & Country & Backdate & $\begin{array}{l}\text { Obj./ } \\
\text { Subj. }\end{array}$ & $\begin{array}{l}\text { Micro/ } \\
\text { Macro }\end{array}$ & $\begin{array}{l}\text { Abs./ } \\
\text { Rel. }\end{array}$ \\
\hline $\begin{array}{l}\text { Barbieri et al. } \\
\text { (2015) }\end{array}$ & $\begin{array}{l}\text { Employment status: } 4 \text { employment categories: } \\
\text { permanent, self-employed, atypical, and non- } \\
\text { standard } \\
\text { Binary indicator of insecure work (atypical or } \\
\text { non-standard) and secure work (permanent or } \\
\text { self-employed). }\end{array}$ & $\mathbf{F}$ & First & $\begin{array}{l}\text { Italy } \\
\text { Spain }\end{array}$ & 12 months & Obj. & Micro & Abs. \\
\hline- & Occupational class: EGP classification system & - & - & - & 12 months & Obj. & Micro & Abs. \\
\hline $\begin{array}{l}\text { Begall } \\
\text { \& Mills } \\
(2011)\end{array}$ & $\begin{array}{l}\text { Job characteristics: } 3 \text { measures: perceived work } \\
\text { control, job strain, importance placed on } \\
\text { combining work and family }\end{array}$ & $\mathbf{F}$ & Intentions & multiple & - & Subj. & Micro & - \\
\hline $\begin{array}{l}\text { Bernardi } \\
\text { \& Nazio } \\
(2005)\end{array}$ & $\begin{array}{l}\text { Occupational class: } 8 \text { occupational } \\
\text { classifications split into economically } \\
\text { secure/insecure }\end{array}$ & B & First & Italy & 9 months & Obj. & Micro & Abs. \\
\hline $\begin{array}{l}\text { Bhaumik \& } \\
\text { Nugent } \\
\text { (2011) }\end{array}$ & $\begin{array}{l}\text { Subjective perception of security: Indicator } \\
\text { combing subjective measure of risk of losing } \\
\text { job (employed) and ease of finding job } \\
\text { (unemployed) }\end{array}$ & $\mathbf{F}$ & $\begin{array}{l}\text { Likelihood of } \\
\text { childbirth }\end{array}$ & $\begin{array}{l}\text { East and } \\
\text { West Germany }\end{array}$ & - & Subj. & Micro & - \\
\hline $\begin{array}{l}\text { Busetta et al. } \\
\text { (2019) }\end{array}$ & $\begin{array}{l}\text { Number and duration of job spells: Indicator } \\
\text { combining number, duration, pairwise } \\
\text { proximity, and recentness of years with } \\
\text { discontinuous employment }\end{array}$ & $\mathrm{C}$ & Intentions & Italy & - & Obj. & Micro & Rel. ${ }^{1}$ \\
\hline $\begin{array}{l}\text { Ciganda } \\
(2015)\end{array}$ & $\begin{array}{l}\text { Number and duration of job spells: Indicator } \\
\text { combining number and duration of spells in } \\
\text { "unstable" states }\end{array}$ & B & First & France & ? & Obj. & Micro & Abs. \\
\hline
\end{tabular}


TABLE A1 (CONTINUED): LIST OF SOURCES AND MEASURES OF EMPLOYMENT UNCERTAINTY

\begin{tabular}{|c|c|c|c|c|c|c|c|c|}
\hline Paper & Measure & Sex* & $\begin{array}{l}\text { Parity/ } \\
\text { Behaviour }\end{array}$ & Country & Backdate & $\begin{array}{l}\text { Obj./ } \\
\text { Subj. }\end{array}$ & $\begin{array}{l}\text { Micro/ } \\
\text { Macro }\end{array}$ & $\begin{array}{l}\text { Abs./ } \\
\text { Rel. }\end{array}$ \\
\hline $\begin{array}{l}\text { Fahlén \& Oláh } \\
\text { (2018) }\end{array}$ & $\begin{array}{l}\text { Subjective perception of security: Job security, } \\
\text { income security }\end{array}$ & B & Intentions & Multiple & - & Subj. & Micro & - \\
\hline- & $\begin{array}{l}\text { Macro: Employment Protection Legislation } \\
\text { Index }\end{array}$ & - & - & - & - & Obj. & Macro & Rel. \\
\hline $\begin{array}{l}\text { Gatta et al. } \\
\text { (2021) }\end{array}$ & $\begin{array}{l}\text { Perception of resilience: Likelihood to lose job, } \\
\text { likelihood to find a new job in case of job loss }\end{array}$ & B & Intentions & Italy & - & Subj. & Micro & - \\
\hline $\begin{array}{l}\text { Golsch } \\
(2003)\end{array}$ & $\begin{array}{l}\text { Employment status: Contract length + full/part- } \\
\text { time }\end{array}$ & B & First & Spain & 12 months & Obj. & Micro & Abs. \\
\hline- & $\begin{array}{l}\text { Subjective perception of security: Job } \\
\text { satisfaction }\end{array}$ & - & - & - & - & Subj. & Micro & - \\
\hline $\begin{array}{l}\text { Guetto et al. } \\
(2020)\end{array}$ & $\begin{array}{l}\text { Experimental methods: Participants read news } \\
\text { about various economic forecasts }\end{array}$ & B & Intentions & Italy & - & Subj. & Macro & - \\
\hline $\begin{array}{l}\text { Hanappi et al. } \\
\text { (2017) }\end{array}$ & $\begin{array}{l}\text { Subjective perception of security: Job security } \\
\text { Indicator of rising or falling insecurity (for } \\
\text { individual and partner) }\end{array}$ & $\mathrm{C}$ & $\begin{array}{l}\text { Intentions to } \\
\text { outcomes }\end{array}$ & Switzerland & - & Subj. & Micro & - \\
\hline $\begin{array}{l}\text { Hofmann } \\
\text { \& Hohmeyer } \\
(2013) \\
\end{array}$ & $\begin{array}{l}\text { Subjective perception of security: Financial } \\
\text { security }\end{array}$ & $\mathbf{F}$ & $\begin{array}{l}\text { Likelihood of } \\
\text { becoming } \\
\text { pregnant }\end{array}$ & Germany & 12 months & Subj. & Micro & - \\
\hline $\begin{array}{l}\text { Kravdal } \\
(2002)\end{array}$ & $\begin{array}{l}\text { Macro: Regional unemployment rate, sector- } \\
\text { specific unemployment rate }\end{array}$ & B & $\begin{array}{l}\text { First } \\
\text { Second+ }\end{array}$ & Norway & 12 months & Obj. & Macro & Abs. \\
\hline Özcan et al. (2010) & $\begin{array}{l}\text { Number and duration of job spells: Number of } \\
\text { months, number of unemployment spells, } \\
\text { number of prior job shifts }\end{array}$ & B & First & Germany & 12 months & Obj. & Micro & Abs. \\
\hline
\end{tabular}


TABLE A1 (CONTINUED): LIST OF SOURCES AND MEASURES OF EMPLOYMENT UNCERTAINTY

\begin{tabular}{|c|c|c|c|c|c|c|c|c|}
\hline Paper & Measure & Sex $^{*}$ & $\begin{array}{l}\text { Parity/ } \\
\text { Behaviour }\end{array}$ & Country & Backdate & $\begin{array}{l}\text { Obj./ } \\
\text { Subj. }\end{array}$ & $\begin{array}{l}\text { Micro/ } \\
\text { Macro }\end{array}$ & $\begin{array}{l}\text { Abs./ } \\
\text { Rel. }\end{array}$ \\
\hline $\begin{array}{l}\text { Pailhé } \\
\text { \& Solaz } \\
\text { (2012) }\end{array}$ & $\begin{array}{l}\text { Employment status: Long-term, short-term, } \\
\text { unemployment, or homemaker } \\
\text { Employment status at union formation }\end{array}$ & B & $\begin{array}{l}\text { First } \\
\text { Completed }\end{array}$ & France & $\begin{array}{l}\text { Previous year }(\mathrm{t}-1) \\
\text { Fixed }\end{array}$ & Obj. & Micro & Abs. \\
\hline- & $\begin{array}{l}\text { Number and duration of job spells: Ratio of } \\
\text { years spent in unemployed/short-term } \\
\text { employment over permanent employment since } \\
\text { union formation }\end{array}$ & - & - & - & $?$ & Obj. & Micro & Abs. \\
\hline- & Macro: Gender-specific unemployment rates & - & - & - & $\begin{array}{l}\text { Previous year } \\
(\mathrm{t}-1)\end{array}$ & Obj. & Macro & Abs. \\
\hline $\begin{array}{l}\text { Schmitt } \\
\text { (2008) }\end{array}$ & $\begin{array}{l}\text { Income: Relative income within partnership } \\
\text { Net personal income }\end{array}$ & B & First & $\begin{array}{l}\text { Finland } \\
\text { France } \\
\text { Germany } \\
\text { UK }\end{array}$ & 10 months & Obj. & Micro & $\begin{array}{l}\text { Rel. } \\
\text { Abs. }\end{array}$ \\
\hline- & $\begin{array}{l}\text { Number and duration of job spells: Number of } \\
\text { long-term employment spells (4+ months) }\end{array}$ & - & - & - & - & Obj. & Micro & Abs. \\
\hline $\begin{array}{l}\text { Schmitt } \\
\text { (2012) }\end{array}$ & Job characteristics: Hours of overtime worked & B & First & $\begin{array}{l}\text { Germany } \\
\text { UK }\end{array}$ & 10 months & Obj. & Micro & Abs. \\
\hline- & $\begin{array}{l}\text { Career making: Index of being underqualified, } \\
\text { properly qualified, or overqualified for first } \\
\text { position }\end{array}$ & - & - & - & - & Obj. $^{2}$ & Micro & Rel. \\
\hline $\begin{array}{l}\text { van Wijk et al. } \\
\text { (2021) }\end{array}$ & Income: Log yearly individual income & $\mathbf{F}$ & First & Netherlands & 9 months & Obj. & Micro & Abs. \\
\hline- & $\begin{array}{l}\text { Subjective perception of security: Individual } \\
\text { perceives risk of losing job and worries about } \\
\text { losing job }\end{array}$ & - & - & - & - & Subj. & Micro & - \\
\hline
\end{tabular}


TABLE A1 (CONTINUED): LIST OF SOURCES AND MEASURES OF EMPLOYMENT UNCERTAINTY

\begin{tabular}{|c|c|c|c|c|c|c|c|c|}
\hline Paper & Measure & Sex $^{*}$ & $\begin{array}{l}\text { Parity/ } \\
\text { Behaviour }\end{array}$ & Country & Backdate & $\begin{array}{l}\text { Obj./ } \\
\text { Subj. }\end{array}$ & $\begin{array}{l}\text { Micro/ } \\
\text { Macro }\end{array}$ & $\begin{array}{l}\text { Abs./ } \\
\text { Rel. }\end{array}$ \\
\hline $\begin{array}{l}\text { Vignoli et al. } \\
(2020)\end{array}$ & Job characteristics: Subjective well-being & $\mathrm{C}$ & $\begin{array}{l}\text { Intentions } \\
\text { (Childless, } \\
\text { Higher parity) }\end{array}$ & Multiple & - & Subj. & Micro & - \\
\hline $\begin{array}{l}\text { Wood \& Neels } \\
\text { (2017) }\end{array}$ & $\begin{array}{l}\text { Employment status: } 11 \text { categories combining } \\
\text { partnership status and partner's employment } \\
\text { status } \\
5 \text { categories of woman's employment status }\end{array}$ & $\mathbf{F}$ & $\begin{array}{l}\text { First } \\
\text { Second } \\
\text { Third }\end{array}$ & Belgium & 12 months & Obj. & Micro & Abs. \\
\hline
\end{tabular}

* $\mathrm{F}=$ Females, $\mathrm{B}=$ Both sexes, $\mathrm{C}=$ Couples.

${ }^{1}$ This indicator is relative by its use in this paper, but can be absolute if used differently.

${ }^{2}$ The index is derived from objective measures with an explicit goal of capturing unreported subjective perceptions. 


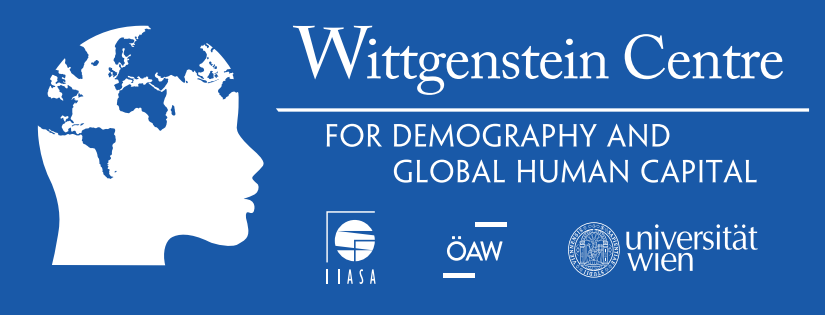

The Wittgenstein Centre is a collaboration among the Austrian Academy of Sciences (ÖAW), the International Institute for Applied Systems Analysis (IIASA) and the University of Vienna. 